\title{
Arisan dalam Menciptakan Harmonisasi antar Masyarakat Panggang, Dusun Prau, Gunung Kidul Yogyakarta
}

\author{
Gisella Arnis Grafiyana ${ }^{1}$, Lingga Bagus Pamungkas ${ }^{2}$, dan Beatrix Marimbunna ${ }^{3}$ \\ ${ }^{1}$ Fakultas Psikologi, Universitas Muhammadiyah Purwokerto ${ }^{2,3}$ Fakultas Psikologi, \\ Universitas Gadjah Mada \\ ${ }^{1}$ Email: gisella.arnis@ump.ac.id
}

\begin{abstract}
ABSTRAK
Konflik dalam kehidupan merupakan hal yang tidak bisa dihindari manusia. Sebagai makhluk sosial, interaksi antar manusia seringkali menyebabkan masalah yang kemudian dapat memunculkan konflik. Sehingga manusia harus memiliki cara untuk mencegah maupun mengatasi kemungkinan apabila terjadi konflik dengan melakukan aktivitas kelompok dengan memegang prinsip gotong royong seperti kerja bakti dan arisan. Resolusi konflik dengan prinsip tersebut juga dipegang erat oleh masyarakat Panggang, Dusun Prau, Gunung Kidul Yogyakarta dan ingin dibahas lebih mendalam pada penelitian ini. Metode yang digunakan dalam penelitian ini adalah metode kualitatif dengan teknik pengumpulan data wawancara dengan dua responden. Hasil menunjukkan arisan (social gathering) merupakan salah satu upaya masyarakat Panggang dalam menyelesaikan konflik. Kegiatan tersebut diperkuat dengan melakukan perubahan positif dan kreatif guna menyamakan persepsi, menyeleraskan perbedaan persepsi yang terjadi sehingga akan memberikan kontribusi untuk membangun perdamaian. Selain menyelesaikan konflik yang muncul, hal lain yang didapat dalam arisan tersebut adalah penanaman nilai-nilai dan menjaga harmonisasi demi mencapai tujuan bersama.
\end{abstract}

Kata Kunci : Arisan ; Resolusi Konflik ; Harmonisasi.

\section{Pendahuluan}

Keberhasilan kelompok dalam upaya untuk memerangi konflik yang sering terjadi dalam kehidupan bermasyarakat baik itu dalam kelompok kecil maupun besar, dalam internal maupun eksternal keluarga maupun pada individu sekalipun. Namun tumbuhnya konflik dapat juga melahirkan sebuah kondisi yang harmonis ketika individu yang tengah berkonflik melakukan upaya-upaya yang positif dalam menyelesaikannya. Upaya untuk menghindari konflik telah banyak dilakukan oleh banyak pihak baik individu maupun kelompok. 
PSISULA: Prosiding Berkala Psikologi

Vol. 1, 2019

E-ISSN: 2715-002X

Terdapat lima metode pemecahan masalah yaitu penghindaran, akomodasi, persaingan, kompromi, dan kolaborasi (Thomas, 1976). Penghindaran yaitu penyelesaian masalah dengan mengabaikan atau menolak untuk mengakui adanya konflik sehingga hasil dari cara ini seringkali tidak mampu memberikan banyak perubahan. Akomodasi merupakan upaya penyelesaian masalah dengan memenuhi kebutuhan atau keinginan, dari sini satu pihak akan merasa lebih diuntungkan daripada pihak lainnya karena umumnya ada yang harus dikorbankan untuk memenuhi kebutuhan tersebut. Persaingan adalah penyelesaian masalah dengan cara bertarung untuk melihat siapa yang lebih unggul. Kompromi merupakan upaya yang disetujui bersama untuk dapat menemukan solusi terbaik sehingga kedua belah pihak yang berkonflik saling menyepakati untuk menyelesaikan masalah.

Mengingat masyarakat Indonesia masih menjunjung prinsip "gotong royong" dalam berinteraksi dengan lingkungan sosialnya baik dalam bentuk kerja bakti maupun arisan, konflik kecil antar tetangga seringkali dapat terselesaikan tanpa membutuhkan intervensi dari pihak di luar masyarakat yang tengah berkonflik. Salah satu bentuk dari kegiatan yang sering dilakukan warga Indonesia yaitu arisan atau social gathering.

Arisan pada dasarnya merupakan aktivitas menabung bersama-sama dalam suatu perkumpulan dengan nilai uang sama setiap orangnya, yang kemudian tabungan tersebut diputar dan diundi sehingga setiap orang akan mendapatkan giliran untuk mendapat uang yang terkumpul tersebut, selain itu arisan juga dapat dijadikan tempat untuk kredit (Chaerani dan Amar, 2010). Sedangkan menurut Sigmund Freud individu yang berkumpul membentuk sebuah massa akan cenderung meninggalkan pola pikir masing-masing dan beralih pada pemikiran kolektif yang dibentuk dalam kelompok tersebut (Ropesta Sitorus, 2014). Selain itu, arisan juga menjadi tempat bersosialisasi dan berkumpulnya sekelompok orang yang berdasarkan kedekatan-kedekatan tertentu entah kedekatan secara geografis, demografis hingga kedekatan secara emosional. Oleh karenanya, arisan tergolong kegiatan yang dapat mengumpulkan berbagai karakter manusia tanpa mengenal kelas sosial. 
PSISULA: Prosiding Berkala Psikologi

Vol. 1, 2019

E-ISSN: 2715-002X

Budaya arisan di Indonesia, terutama di Jawa, dalam pengundiannya apabila salah satu anggota mendapatkan uang arisan pada pengundian, anggota tersebut memiliki kewajiban untuk menggelar pertemuan arisan pada periode berikutnya. Arisan sendiri sering ditemukan pada pertemuan-pertemuan resmi yang diatur di tingkat hirarki yang berbeda dari desa/kelurahan atau dusun/lingkungan tetangga (Chaerani dan Amar, 2010). Selain menjadi media bertemu, dalam arisan juga terdapat interaksi sosial yang dapat membantu menyelesaikan konflik yang muncul antaranggota arisan. Penelitian ini mencoba membahas arisan dari segi dinamika di dalamnya dalam resolusi konflik.

\section{Metode}

Subjek dalam penelitian ini merupakan dua warga Dusun Prau, Panggang Yogyakarta yang merupakan seorang bapak dan ibu rumah tangga. Metode pengambilan data dalam penelitan ini dilakukan melalui wawancara yang dirancang untuk menggali dan mencoba memahami berbagai permasalahan yang dialami oleh Dusun Prau serta dinamika resolusi konflik dalam mengatasinya.

\section{Hasil}

Temuan yang dikemukakan responden terkait permasalahan yang muncul di Dusun Prau salah satunya adalah perselisihan antar pemuda dengan Rukun Tangga (RT) lain ketika perayaan hari kemerdekaan 17 Agustus yang dirayakan setiap setahun sekali. Perayaan itu berupa perlombaan voli yang sangat digemari masyarakat Dusun Prau, namun juga berisiko menimbulkan konflik antar-RT karena perselisihan antar pemain dan supporter yang ingin menjadi pemenang. Sehingga kemungkinan terjadinya pertikaian pun cenderung meningkat dan sulit untuk dihindari.

Ada beberapa penyebab pertikaian antar warga di Desa Prau dapat terjadi, salah satunya yaitu adanya kompetisi antar pemuda yang sangat tinggi. Baik pemain dan warganya dianggap rela melakukan segala untuk memenangkan ajang bergengsi tersebut karena hal itu dapat meningkatkan harga diri masing-masing 
PSISULA: Prosiding Berkala Psikologi

Vol. 1, 2019

E-ISSN: 2715-002X

kelompok. Dari persaingan dalam berkompetisi inilah kemudian muncul prasangkaprasangka negatif, misalnya, menuduh pesaing-pesaing dalam perlombaan melakukan kecurangan atau bahkan menggunakan praktek dukun agar dapat memenangkan kompetisi tersebut. Prasangka-prasangka tersebut kemudian menimbulkan konflik antar kelompok, di mana konflik itu termanifestasikan ke dalam perilaku agresif hingga menjurus ke pertikaian.

Ada beberapa golongan arisan (social gathering) di Dusun Prau yang dibentuk warga setempat yaitu golongan pemuda-pemudi, golongan orangtua, golongan umum (seluruh warga dusun Prau). Data yang didapatkan oleh responden mengenai kegiatan arisan (social gathering) di mana hasil dari pengumpulan uang arisan akan digunakan untuk kepentingan bersama warga dusun, seperti halnya kegiatan perayaan hari-hari besar, kematian penduduk setempat, dan hal-hal yang sifatnya darurat yang mengharuskan dana arisan untuk terpakai.

Ketika muncul suatu pertikaian, masyarakat kemudian menjadi bersitegang dalam berinteraksi bahkan hal ini bisa berlangsung cukup lama. Dengan adanya arisan rutin, maka mau tidak mau akhirnya masyarakat berinteraksi meskipun sedang bersitegang. Sehingga kesalahpahaman antar warga yang awalnya sangat tinggi bisa terurai dengan berinteraksi langsung dan menyamakan pandangan. Dari pertemuan ini, warga yang awalnya berkonflik akan kesulitan berkomunikasi dan segan untuk menyapa, kemudian setelah beberapa pertemuan terpaksa berinteraksi karena kondisi arisan mengharuskan bertemu dalam waktu lama. Akhirnya dari arisan ini, warga yang tengah berkonflik dapat menemukan solusinya secara alami.

\section{Diskusi}

Menurut Gillin \& Gillin (1954) pertikaian dan perselisihan merupakan bentuk dari interaksi sosial yang termasuk ke dalam proses disosiatif. Persaingan dapat diartikan sebagai suatu proses sosial di mana individu atau kelompok saling bersaing, mencari keuntungan, melalui berbagai bidang kehidupan yang pada suatu masa tertentu dan menjadi pusat perhatian umum dengan cara menarik perhatian 
PSISULA: Prosiding Berkala Psikologi

Vol. 1, 2019

E-ISSN: 2715-002X

publik atau dengan mempertajam prasangka yang ada, tanpa menggunakan ancaman atau kekerasan. Sedangkan persaingan yang meliputi kontroversi dan pertentangan disebut pertikaian. Pertikaian biasanya diawali dari rasa perbedaan pribadi maupun kelompok. Pertikaian adalah suatu proses sosial dimana individu atau kelompok berusaha untuk memenuhi tujuannya dengan jalan menantang pihak lawan yang disertai dengan ancaman hingga kekerasan. Terjadinya interaksi dissosiatif pun ditemukan pada masyarakat Dusun Prau yang seringkali mengadakan kegiatan bersama dan memunculkan ketegangan.

Egosentrisme, ketegangan, dan kompetisi merupakan ekspresi terhadap kekerasan. Dibawah kondisi tersebut muncul kondisi yang berlawanan seperti alturisme, kerjasama atau gotong royong. Kondisi-kondisi tersebut bisa diartikan sebagai upaya masyarakat dalam menemukan harmonisasi, dan memandang arisan yang dilakukan di Dusun Prau menjadi salah satu cara menaungi segala permasalahan yang kerap muncul di luar kegiatan sosial ini. Karena intesitas pertemuan yang dilakukan tiap kali kegiatan arisan (social gathering) ini diadakan dapat mencairkan suasana yang awalnya berselisih dapat saling menghargai satu sama lain, modal sosial positif inilah yang dapat memunculkan jiwa gotong royong yang selama ini dianut oleh warga Dusun Prau.

Kegiatan social gathering memiliki pengaruh bagi warga dalam mengurangi ketegangan antar kelompok, sehingga kegiatan social gathering tersebut dapat membangun rasa kerja sama atau gotong royong yang dimana dalam gotong royong tugas-tugas yang diperlukan kelompok untuk bekerja sama untuk mencapai suatu tujuan tidak bisa dicapai secara mandiri. Arisan memiliki peran yang erat kaitannya dalam meredakan ketegangan atau perselisihan yang terjadi antar kelompok dan dapat meningkatkan pengertian serta pemahaman antar kelompok yang saling bertikai. Arisan (social gathering) memfokuskan upaya pada perubahan positif dan kreatif yang akan memberikan kontribusi untuk membangun perdamaian dan untuk menanamkan nilai-nilai dan bekerja bersama menuju tujuan bersama.

Menurut Chaerani dan Amar (2010) arisan selain berfungsi moneter juga memiliki fungsi asosiasi sosial sebagai bentuk gotong royong atau kerja sama yang 
PSISULA: Prosiding Berkala Psikologi

Vol. 1, 2019

E-ISSN: 2715-002X

tidak hanya berkaitan dengan uang tetapi ada tujuan lain seperti yang telah dilakukan oleh arisan di beberapa kecamatan di mana penerima arisan telah menggunakan uang itu untuk memperbaiki rumah-rumah dengan bantuan warga setempat, atau bahkan membeli sepeda motor untuk mendukung pendapatannya.

\section{Kesimpulan}

Berdasarkan hasil dan diskusi yang sudah telah dipaparkan, dapat disimpulkan bahwa sebuah konflik merupakan hal umum yang sering terjadi dalam kehidupan bermasyarakat. Namun, di dalam konflik tersebut masyarakat juga telah menyiapkan strategi pencegahan dan resolusi konflik dalam bentuk berkelompok juga seperti arisan dan gotong royong. Sehingga arisan menjadi salah satu cara yang mampu berkontribusi dalam penurunan ketegangan yang muncul akibat dari konflik yang terjadi dengan dinamika interaksi sosial yang terjadi pada saat arisan tersebut. 
PSISULA: Prosiding Berkala Psikologi

Vol. 1, 2019

E-ISSN: 2715-002X

\section{DAFTAR PUSTAKA}

Chaerani, S., dan Amar, D. (2010). Gunem Catur in the Sunda region of West Java: indigenous communication on MAC plant knowledge and practice within the Arisan in Lembang, Indonesia. Doctoral Thesis. Leiden University: Faculteit der Wiskunde en Natuurwetenschappen.

Gillin, J. L., \& Gillin, J. P. (1954). Cultural Sociology. New York: The Macmilan Company.

Thomas, K. (1976). Handbook of Industrial \& Organizational Psychology, "Conflict \& Conflict Management." Chicago: Rand McNally.

Sitorus,R. (2014). Mengintip arisan sosialita Jakarta : Sosialita antara tas ratusan juta hingga barang tiruan. http://news.detik.com diakses pada tanggal 20 September 2019 pukul 19:38 